\title{
CHARACTERIZATION OF NEW AND ARTIFICIALLY AGED PARCHMENTS
}

\section{Lucreţia MIU ${ }^{1 *}$, Elena BADEA ${ }^{1,2}$, Claudiu ŞENDREA ${ }^{1}$}

${ }^{1}$ INCDTP - Division: Leather and Footwear Research Institute, 93 Ion Minulescu st., 030215 Bucharest, Romania,

$$
\text { lucretia.miu@icpi.ro }
$$

2Department of Chemistry, Faculty of Sciences, University of Craiova, Calea Bucureşti 107 I, 200585 Craiova, Romania

\section{CHARACTERIZATION OF NEW AND ARTIFICIALLY AGED PARCHMENTS}

ABSTRACT. This study aims to characterize new and artificially aged parchments. Parchment samples of calf, sheep, goat and pig were exposed to artificial ageing at $70^{\circ} \mathrm{C}$ in 3 cycles: first cycle for 7 days, second cycle for 14 days and 21 days for the $3^{\text {rd }}$ cycle. Thus, a treatment temperature of $70^{\circ} \mathrm{C}$ was selected to avoid sudden structural changes and rapid collagen denaturation. To evaluate the deterioration degree of parchments, the samples exposed to the first cycle were subjected to physical-mechanical, chemical tests and shrinkage temperature while the samples exposed to the second and $3^{\text {rd }}$ cycle to physical-mechanical test. Depending on the ageing cycles significant changes were reported. The accelerated ageing of parchments degraded the physical-mechanical properties and lowered the shrinkage temperature. The behavior of sheep and goat parchment samples to accelerated ageing suggests a rather high deterioration in the hydrothermal stability. KEYWORDS: physical-mechanical properties, shrinkage temperature, parchment, collagen, accelerated ageing

\section{CARACTERIZAREA PERGAMENTELOR NOI ŞI ÎMBĂTRÂNITE ARTIFICIAL}

REZUMAT. Acest studiu își propune să caracterizeze pergamentele noi și îmbătrânite artificial. Probe de pergament de vițel, oaie, capră și porc au fost expuse la îmbătrânire artificială la $70^{\circ} \mathrm{C}$ în 3 cicluri: primul ciclu timp de 7 zile, al doilea ciclu timp de 14 zile și 21 de zile pentru al 3-lea ciclu. A fost selectată astfel o temperatură de tratare de $70^{\circ} \mathrm{C}$ pentru a evita schimbările bruște structurale și denaturarea rapidă a colagenului. Pentru a evalua gradul de deteriorare a pergamentelor probele expuse la primul ciclu de îmbătrânire au fost testate prin analize fizico-mecanice, chimice și temperatura de contracție, iar probele expuse la ciclurile II și III la analize fizico-mecanice. În funcție de ciclurile de îmbătrânire au fost raportate modificări semnificative. Îmbătrânirea accelerată a pergamentelor a produs degradări ale proprietăților fizicomecanice și ale temperaturii de contracție. Comportamentul probelor de pergament de ovine și caprine la îmbătrânirea accelerată sugerează o deteriorare destul de mare a stabilității hidrotermice.

CUVINTE CHEIE: proprietăți fizico-mecanice, temperatura de contracție, pergament, colagen, îmbătrânire accelerată

\section{CARACTÉRISATION DES PARCHEMINS NOUVEAUX ET ÂGÉS ARTIFICIELLEMENT}

RÉSUMÉ. Cette étude vise à caractériser les parchemins nouveaux et artificiellement âgés. Des échantillons de parchemin de veau, mouton, chèvre et porc ont été exposés au vieillissement artificiel à $70^{\circ} \mathrm{C}$ en 3 cycles : premier cycle pendant 7 jours, deuxième cycle pendant 14 jours et 21 jours pour le $3^{\mathrm{e}}$ cycle. Ainsi on a choisi une température de traitement de $70^{\circ} \mathrm{C}$ pour éviter les changements structurels soudains et dénaturation rapide du collagène. Des tests physico-mécaniques, chimiques et de température de retrait ont été utilisés pour évaluer le degré de détérioration des parchemins. Selon les cycles de vieillissement, des changements importants ont été signalés. Le vieillissement accéléré des parchemins a provoqué des dégradations des propriétés physico-mécaniques et de la température de retrait. Le comportement des échantillons de parchemins de mouton et de chèvre au vieillissement accéléré suggère une détérioration assez élevée de la stabilité hydrothermale.

MOTS CLÉS : propriétés physico-mécaniques, température de retrait, parchemin, collagène, vieillissement accéléré

\footnotetext{
* Correspondence to: Lucreția MIU, INCDTP - Division: Leather and Footwear Research Institute, 93 Ion Minulescu st., 030215 Bucharest, Romania, lucretia.miu@icpi.ro
} 


\section{INTRODUCTION}

Used for writing purposes, parchment is a very stable biomaterial, but it has a major drawback: it degrades with time. One of the oldest materials of cultural interest, parchment can survive for long periods of time if proper conditions are maintained. A fascinating discovery in 1947, in the caves of Qumram, dating from the beginning of 250 B.C. up to 68 A.D., has revealed one of the oldest preserved parchment manuscripts (Dead Sea Scrolls) [1]. These artefacts are a unique and nonrenewable resource whose protection requires a thorough knowledge about the materials, their deterioration processes and the factors that cause them.

Studies on the damage of parchment have highlighted that their deterioration is due to environmental factors (temperature, humidity, light, pollution), biological factors (bacteria, fungi, rodents, insects) and chemical factors (acids, bases, oxygen, ozone, ultraviolet radiation) [2]. These factors cause numerous structural changes that must be understood scientifically to achieve appropriate restoration-conservation treatment with compatible materials.

Throughout the centuries, the manufacturing technologies of parchment have varied. The pre-medieval parchment was lightly tanned with vegetable matter and in the medieval period alkaline limestone baths were used [1, 3]. Although parchment manufacturing technologies have been modernized, they are based on medieval recipes using alkaline lime solutions [4-6]. Due to the number of components introduced in the fabrication process, parchment is subjected during production to changes in the structure of collagen. The hierarchical structure of the collagen (molecules, fibrils, fibers) in parchment determines the mechanical properties of resistance. Parchments are complex systems consisting of collagen where added solids and liquids are dispersed or dissolved in the substrate. These solids and liquids interact with each other in different processing stages.

Frequently handling the parchments by everyday use can result in mechanical damage. The processes of physical-chemical deterioration of the parchment structure have so far been little studied. In this study we aim to characterize new and artificially aged parchments by physical- mechanical, chemical tests and shrinkage temperature.

\section{EXPERIMENTAL}

For this study, parchment was prepared using technology inspired from ancient recipes at the Leather and Footwear Research Institute (ICPI) of the National Research and Development Institute for Textiles and Leather (INCDTP), Bucharest. In the current technological process of parchment manufacturing, skins preserved by salting $[1,4,5,7]$ were used. The first stage of skin processing, soaking, is done with clean water of about $22^{\circ} \mathrm{C}$. After soaking and fleshing the liming operation is performed, $6-8 \% \mathrm{Ca}(\mathrm{OH})_{2}$, whose main objective is the removal of the epidermis and hair. The skins are treated with a solution of lime for 3-4 days. The mechanical or manual fleshing is done before the second liming operation of about 2-3 days, $3-4 \% \mathrm{Ca}(\mathrm{OH})_{2}$. Then, deliming and washing operations are performed and at the end the skin is stretched over a wooden frame and left to dry $[8,9]$.

The samples were cut with the help of a press knife $110 \mathrm{~mm}$ long and $30 \mathrm{~mm}$ wide for the elongation at a load of $10 \mathrm{~N} / \mathrm{mm}^{2}$ and elongation at break, $80 \mathrm{~mm}$ long and $40 \mathrm{~mm}$ wide for the tensile strength, $120 \mathrm{~mm}$ long and $30 \mathrm{~mm}$ wide for the tear strength and for the dimensional stability the specimens were cut $80 \mathrm{~mm}$ long and $60 \mathrm{~mm}$ wide, $50 \mathrm{~mm}$ long and $40 \mathrm{~mm}$ wide and square with the side of $40 \mathrm{~mm}$.

The parchment samples underwent artificial ageing treatments by heating at fixed temperature. Parchment samples of calf (C), sheep $(S)$, goat $(G)$ and pig $(P)$ were exposed to artificial ageing at $70^{\circ} \mathrm{C}$ in 3 cycles: first cycle for 7 days, second cycle for 14 days and 21 days for the $3^{\text {rd }}$ cycle. Thus, a treatment temperature of $70^{\circ} \mathrm{C}$ was selected to avoid sudden structural changes and rapid collagen denaturation [10, 11]. To evaluate the deterioration degree of parchments, the samples exposed to the first cycle were subjected to physical-mechanical, chemical tests and shrinkage temperature, while the samples exposed to the second and $3^{\text {rd }}$ cycle to physical-mechanical test.

Physical-chemical characteristics of new and artificially aged parchment samples (Table 1 and Table 2) were determined according to standardised methods for obtaining moisture, 
extractable substances, combined fat substances, total fat substances, total ash, total nitrogen, ammoniacal nitrogen, protein nitrogen and $\mathrm{pH}$ [12-16].

Shrinkage activity was evaluated by the SR EN ISO 3380: 2003 method. The method is useful in cases where the shrinkage temperature is below $100^{\circ} \mathrm{C}$ and it is used as a means of quality control in different stages of the technological process of manufacturing parchment. At INCDTP-ICPI, determination of the shrinkage temperature is performed with the Giuliani IG/ TG equipment. The $50 \mathrm{~mm}$ long and $3 \mathrm{~mm}$ wide specimen is perforated and attached to the support hook. Before determining the shrinkage temperature, the specimen is conditioned by immersion in water for a few minutes for saturation. This will rehydrate the sample and facilitate the perforation by the two hooks. Then, it is immersed in the vessel filled with water. The vessel is then heated slowly at $2^{\circ} \mathrm{C} / \mathrm{min}$, and the shrinkage temperature is visually determined by an operator, this being identified with the moment when the specimen is contracted.

The samples of parchments were also subjected to standardized physical-mechanical tests [17], before and after artificial ageing.

\section{RESULTS AND DISCUSSION}

\section{Chemical Characteristics}

The chemical characteristics fall within the limits imposed. After artificial ageing ( 7 days at $70^{\circ} \mathrm{C}$ ) only humidity shows losses of $10 \pm 2 \%$. The other characteristics have no significant variations (Table 1 and Table 2).

Table 1: Physical-chemical characteristics of untreated parchments

\begin{tabular}{lcccccc}
\hline \multirow{2}{*}{ No. } & \multirow{2}{*}{ Characteristics } & \multirow{2}{*}{ MU } & \multicolumn{5}{c}{ Sample code/Values } \\
\hline 1 & Moisture & $\%$ & 17.33 & 17.56 & 18.24 & 18.51 \\
2 & Extractable substances & $\%$ & 5.61 & 0.61 & 2.23 & 0.20 \\
3 & Combined fat ubstances & $\%$ & 1.66 & 0.70 & 3.30 & 0.72 \\
4 & Total fat substances & $\%$ & 7.27 & 1.31 & 5.53 & 1.02 \\
5 & Total Ash & $\%$ & 2.20 & 3.87 & 1.98 & 9.42 \\
6 & Total Nitrogen & $\%$ & 18.52 & 17.90 & 17.43 & 15.18 \\
7 & Ammoniacal Nitrogen & $\%$ & 0.22 & 0.13 & 0.10 & - \\
8 & Protein Nitrogen & $\%$ & 18.30 & 17.77 & 17.32 & 15.18 \\
9 & $\mathrm{pH}$ & $\%$ & 6.2 & 6.3 & 6.2 & 6.8 \\
\hline
\end{tabular}

Table 2: Physical-chemical characteristics of artificially aged parchments

\begin{tabular}{lcccccc}
\hline \multirow{2}{*}{ No. } & Characteristics & MU & \multicolumn{5}{c}{ Sample code/Values } \\
\hline 1 & Moisture & $\%$ & 15.40 & 16.50 & 16.40 & 16.50 \\
2 & Extractable substances & $\%$ & 5.61 & 0.61 & 2.23 & 0.2 \\
3 & Combined fat substances & $\%$ & 1.66 & 0.70 & 3.30 & 0.72 \\
4 & Total fat substances & $\%$ & 7.27 & 1.31 & 5.53 & 1.02 \\
5 & Total Ash & $\%$ & 2.20 & 3.87 & 1.98 & 9.42 \\
6 & Total Nitrogen & $\%$ & 18.52 & 17.90 & 17.43 & 15.18 \\
7 & Ammoniacal Nitrogen & $\%$ & 0.22 & 0.13 & 0.10 & - \\
8 & Protein Nitrogen & $\%$ & 18.30 & 17.77 & 17.32 & 15.18 \\
9 & $\mathrm{pH}$ & $\%$ & 6.2 & 6.3 & 6.2 & 6.8 \\
\hline
\end{tabular}




\section{Effect of Accelerated Ageing on Thermal Stability}

Shrinkage temperature is a standard feature of leather and parchment. When collagen fibers are heated in water, they contract in length at a specific temperature [6, 18-20], which depends on the strength or quality of the leather and the degree of its deterioration.
Collagen fiber contraction represents the macroscopic manifestation of the process of thermal denaturation of collagen molecules, a process that results in the collapse of the structure of the triple helix, whose integrity is essential for maintaining the mechanical, structural, physical-chemical and functional properties of the collagen materials.

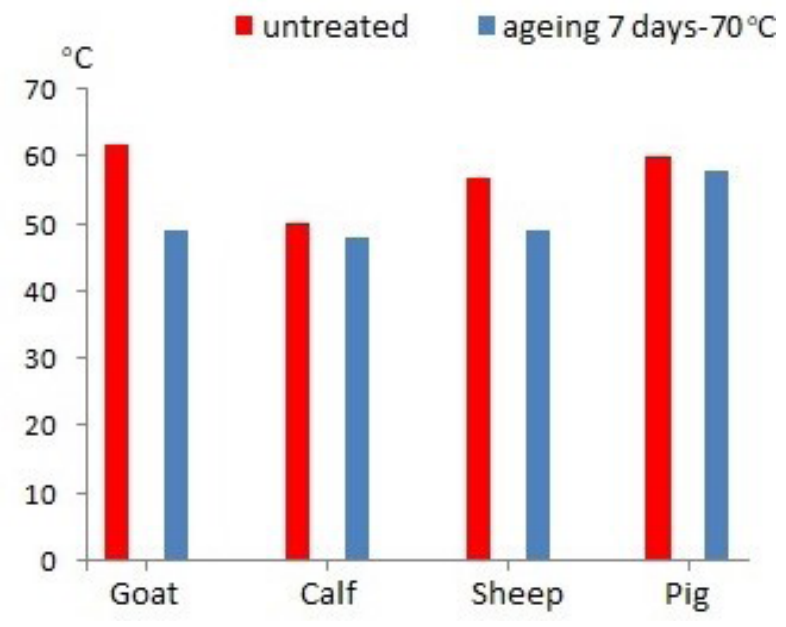

Figure 1. Variation of shrinkage temperature before and after accelerated ageing treatment

In Figure 1 we can see a comparison of shrinkage temperature among parchment samples before and after accelerated ageing treatment at $70^{\circ} \mathrm{C}$ for 7 days.

Shrinkage temperatures showed a rather good hydrothermal stability for the untreated parchment samples; shrinkage temperature differs depending on the characteristics of the skin of the animal species (goat, calf, sheep and pig).

The shrinkage temperature decreases by $3-4$ to $15-20 \%$ in the artificially aged samples compared to the control samples. From Figure 1 we can observe in the case of calf and pig parchment samples a better withstand to the destabilizing effects, with only $2^{\circ} \mathrm{C}$ decrease. The sheep and goat samples were the least resistant to the ageing treatment, with a decrease of 8 to $13^{\circ} \mathrm{C}$.

\section{Physical-Mechanical Tests}

The parchment sample were analysed from the physical-mechanical point of view, before and after artificial ageing (Table 3 ).

Table 3: Physical-mechanical characteristics of the goat parchment - sample G, for the untreated sample and after the accelerated ageing cycles (cycle I, cycle II, cycle III)

\begin{tabular}{|c|c|c|c|c|c|c|c|c|c|}
\hline \multirow[b]{2}{*}{$\begin{array}{l}\text { Characteristics } \\
\text { Treatment }\end{array}$} & \multirow[b]{2}{*}{$\begin{array}{c}\text { Thickness } \\
\mathrm{mm}\end{array}$} & \multicolumn{2}{|c|}{ Elongation \% } & \multirow[b]{2}{*}{$\begin{array}{l}\text { Tensile } \\
\text { strength } \mathrm{N} / \\
\mathrm{mm}^{2}\end{array}$} & \multirow[b]{2}{*}{$\begin{array}{c}\text { Tear } \\
\text { strength } \\
\mathrm{N} / \mathrm{mm}\end{array}$} & \multicolumn{4}{|c|}{ Dimensional stability (shrinkage) \% } \\
\hline & & $\begin{array}{c}\text { at a load } \\
\text { of } \\
10 \mathrm{~N} / \mathrm{mm}^{2}\end{array}$ & $\begin{array}{l}\text { at } \\
\text { break }\end{array}$ & & & Length & Width & Surface & Thickness \\
\hline \multirow{3}{*}{$\begin{array}{l}\text { Sample G } \\
\text { untreated }\end{array}$} & $a-0.25$ & 10 & 26 & 61.7 & 33.3 & & & & \\
\hline & $b-0.24$ & 8 & 24 & 53.3 & 44.4 & & & & \\
\hline & average & 9 & 25 & 57.5 & 38.8 & & & & \\
\hline
\end{tabular}




\begin{tabular}{|c|c|c|c|c|c|c|c|c|c|}
\hline \multicolumn{10}{|c|}{ Parchment $\mathrm{G}$ exposed to artificial ageing } \\
\hline Ageing & $a-0.21$ & 6 & 28 & 51.2 & 45.4 & 2.8 & 2.2 & 4.9 & 0 \\
\hline 7 days $-70^{\circ} \mathrm{C}$ & $b-0.22$ & 4 & 28 & 54.8 & 40.9 & 2.3 & 1.7 & 4.0 & 0 \\
\hline cycle I & average & 5 & 28 & 53.0 & 43.1 & 2.5 & 1.9 & 4.4 & 0 \\
\hline Ageing & $a-0.25$ & 6 & 30 & 87.2 & 43.5 & 3.2 & 3.0 & 6.0 & 0 \\
\hline 14 days $-70^{\circ} \mathrm{C}$ & $b-0.30$ & 8 & 32 & 83.3 & 37.5 & 3.2 & 2.2 & 5.3 & 0 \\
\hline cycle II & average & 7 & 31 & 85.2 & 40.5 & 3.2 & 2.6 & 5.6 & 0 \\
\hline Ageing & $a-0.26$ & 8 & 36 & 51.2 & 37.5 & 4.1 & 4.2 & 8.1 & 0 \\
\hline 21 days $-70^{\circ} \mathrm{C}$ & $b-0.25$ & 8 & 30 & 46.8 & 28.6 & 3.8 & 3.3 & 7.0 & 0 \\
\hline cycle III & average & 8 & 33 & 49.0 & 33.0 & 3.9 & 3.7 & 7.5 & 0 \\
\hline
\end{tabular}

From Table 3 it can be observed that the applied oxidizing ageing cycles lead to the following physical-mechanical changes:

- The elongation at a load of $10 \mathrm{~N} / \mathrm{mm}^{2}$ decreases by $56 \%$ after the first cycle, increases by $40 \%$ in the second cycle compared to the first cycle, increases by $14 \%$ in the third cycle compared to second cycle and in the third cycle it is close to the value of the untreated sample;

- The elongation at break remains almost constant over the three cycles;

- Tensile strength decreases by $8 \%$ in cycle I as compared to control sample, in cycle II it increases by $38 \%$ as compared to cycle I, and in cycle III it decreases by $42 \%$ as compared to cycle II and by $15 \%$ as compared to control sample;

- The tear strength increases by $10 \%$ in cycle I compared to the control sample, in cycle II it decreases by $6 \%$ compared to cycle I, and in cycle III it reaches the value of the control sample;
- The decrease of the surface of the parchments after each cycle of thermal ageing is progressive.

These characteristics fall within the limits imposed by standards.

The analysis of the results shown in Table 3 has allowed the evaluation of the degradation state of the parchments. The results of the ageing behaviour showed that the ageing treatment at $70^{\circ} \mathrm{C}$, in several cycles, produced a degradation of the physical mechanical properties of resistance that materialized also by lowering the shrinkage temperature by $2-10^{\circ} \mathrm{C}$. This allowed us to select the parchment variants which showed the smallest dimensional change after artificial ageing (an essential requirement for the parchment used in the museum field, which ensures a stable behaviour, preventing the formation of tensions that lead to damage).

The calf parchment was characterized in the same way (Table 4).

Table 4: Physical-mechanical characteristics of the calf parchment - sample C, for the untreated sample and after the accelerated ageing cycles (cycle I, cycle II, cycle III)

\begin{tabular}{|c|c|c|c|c|c|c|c|c|c|}
\hline \multirow{2}{*}{$\begin{array}{l}\text { Characteristics } \\
\text { Treatment }\end{array}$} & \multirow{2}{*}{$\begin{array}{c}\text { Thickness } \\
\mathrm{mm}\end{array}$} & \multicolumn{2}{|c|}{ Elongation \% } & \multirow{2}{*}{$\begin{array}{c}\text { Tensile } \\
\text { strength } \\
\mathrm{N} / \mathrm{mm}^{2}\end{array}$} & \multirow{2}{*}{$\begin{array}{c}\text { Tear } \\
\text { strength } \\
\mathrm{N} / \mathrm{mm}\end{array}$} & \multicolumn{4}{|c|}{ Dimensional stability (shrinkage) \% } \\
\hline & & $\begin{array}{c}\text { at a load } \\
\text { of } \\
10 \mathrm{~N} / \mathrm{mm}^{2}\end{array}$ & $\begin{array}{c}\text { at } \\
\text { break }\end{array}$ & & & Length & Width & Surface & Thickness \\
\hline \multirow{3}{*}{$\begin{array}{l}\text { Sample C } \\
\text { untreated }\end{array}$} & $a-0.44$ & 6 & 32 & 117.3 & 52.1 & & & & \\
\hline & $b-0.44$ & 14 & 32 & 104.2 & 54.9 & & & & \\
\hline & average & 10 & 32 & 110.7 & 53.5 & & & & \\
\hline \multicolumn{10}{|c|}{ Parchment $\mathrm{C}$ exposed to artificial ageing } \\
\hline \multirow{3}{*}{$\begin{array}{c}\text { Ageing } \\
7 \text { days }-70^{\circ} \mathrm{C} \\
\text { cycle I }\end{array}$} & a -0.49 & 6 & 30 & 90.9 & 32.2 & 3.2 & 3.4 & 6.6 & 6.0 \\
\hline & $b-0.45$ & 6 & 32 & 109.3 & 23.3 & 3.6 & 4.2 & 7.7 & 3.2 \\
\hline & average & 6 & 31 & 100.1 & 27.7 & 3.4 & 3.8 & 7.1 & 4.6 \\
\hline \multirow{3}{*}{$\begin{array}{c}\text { Ageing } \\
14 \text { days }-70^{\circ} \mathrm{C} \\
\text { cycle II }\end{array}$} & $a-0.60$ & 6 & 28 & 99.1 & 38.6 & 3.9 & 4.8 & 8.4 & 7.6 \\
\hline & $b-0.54$ & 8 & 32 & 130.6 & 48.4 & 3.9 & 4.3 & 7.9 & 9.7 \\
\hline & average & 7 & 30 & 101.1 & 43.5 & 3.9 & 4.5 & 8.1 & 8.6 \\
\hline
\end{tabular}




\begin{tabular}{cllllllllll} 
Ageing & a -0.62 & 8 & 28 & 113.5 & 66.2 & 4.2 & 4.8 & 8.8 & 7.6 & \\
21 days $-70^{\circ} \mathrm{C}$ & b- 0.58 & 6 & 30 & 92.7 & 33.3 & 4.2 & 4.3 & 8.4 & 9.7 & 8.6 \\
cycle III & average & 7 & 29 & 103.1 & 49.7 & 4.2 & 4.5 & 8.6 & 8.6 \\
\hline
\end{tabular}

From Table 4 it can be observed that the thermal ageing cycles applied to sample $\mathrm{C}$ lead to the following changes in physical-mechanical resistance:

- The elongation at a load of $10 \mathrm{~N} / \mathrm{mm}^{2}$ decreases by $40 \%$ after cycle I then remains constant in cycles II and III;

- The elongation at break remains constant during the three cycles of ageing;

- The tensile strength remains constant during the three ageing cycles;
- The tear strength decreases by $48 \%$ after cycle I, increases by $36 \%$ in cycle II compared to cycle I, and in cycle III it increases by $12.5 \%$ compared to cycle II, and approaches the value of the control sample;

- Dimensional stability gradually decreases in cycles I, II and III.

The characteristics of the sheep parchment are presented in Table 5.

Table 5: Physical-mechanical characteristics of the sheep parchment - sample S, for the untreated sample and after the accelerated ageing cycles (cycle I, cycle II, cycle III)

\begin{tabular}{|c|c|c|c|c|c|c|c|c|c|}
\hline \multirow{2}{*}{$\begin{array}{c}\text { Characteristics } \\
\text { Treatment }\end{array}$} & \multirow{2}{*}{$\begin{array}{c}\text { Thickness } \\
\mathrm{mm}\end{array}$} & \multicolumn{2}{|c|}{ Elongation \% } & \multirow{2}{*}{$\begin{array}{c}\text { Tensile } \\
\text { strength } \\
\mathrm{N} / \mathrm{mm}^{2}\end{array}$} & \multirow{2}{*}{$\begin{array}{c}\text { Tear } \\
\text { strength } \\
\mathrm{N} / \mathrm{mm}\end{array}$} & \multicolumn{4}{|c|}{ Dimensional stability (shrinkage) \% } \\
\hline & & $\begin{array}{c}\text { at a load } \\
\text { of } 10 \mathrm{~N} / \\
\mathrm{mm}^{2}\end{array}$ & $\begin{array}{c}\text { at } \\
\text { break }\end{array}$ & & & Length & Width & Surface & Thickness \\
\hline $\begin{array}{l}\text { Sample S } \\
\text { untreated }\end{array}$ & $\begin{array}{l}\mathrm{a}-0.56 \\
\mathrm{~b}-0.44 \\
\text { average }\end{array}$ & $\begin{array}{l}6 \\
8 \\
7 \\
\end{array}$ & $\begin{array}{l}24 \\
28 \\
26 \\
\end{array}$ & $\begin{array}{l}40.6 \\
41.1 \\
40.8 \\
\end{array}$ & $\begin{array}{l}13.2 \\
21.6 \\
17.4 \\
\end{array}$ & & & & \\
\hline \multicolumn{10}{|c|}{ Parchment $\mathrm{S}$ exposed to artificial ageing } \\
\hline Ageing & $a-0.40$ & 6 & 22 & 39.5 & 13.0 & 1.9 & 2 & 4.0 & 0 \\
\hline 7 days $-70^{\circ} \mathrm{C}$ & $b-0.38$ & 6 & 20 & 34.7 & 7.5 & 2.5 & 2 & 4.8 & 2.9 \\
\hline cycle I & average & 6 & 21 & 37.1 & 10.2 & 2.2 & 2 & 4.4 & - \\
\hline Ageing & $\mathrm{a}-0.32$ & 8 & 30 & 40.2 & 12.8 & 3.2 & 3.7 & 6.8 & 3.1 \\
\hline 14 days $-70^{\circ} \mathrm{C}$ & $b-0.53$ & 8 & 28 & 35.0 & 16.7 & 3.8 & 2.9 & 6.7 & 2.9 \\
\hline cycle II & average & 8 & 29 & 37.6 & 14.7 & 3.5 & 3.3 & 6.7 & 3.0 \\
\hline Ageing & $a-0.50$ & 10 & 28 & 29.5 & 9.2 & 3.2 & 3.7 & 6.8 & 3.1 \\
\hline 21 days $-70^{\circ} \mathrm{C}$ & $b-0,37$ & 12 & 26 & 29,1 & 7.3 & 3.8 & 2.9 & 6.7 & 0 \\
\hline cycle III & average & 11 & 27 & 29.3 & 8.2 & 3.5 & 3.3 & 6.7 & - \\
\hline
\end{tabular}

From Table 5 it can be observed that the applied thermal ageing cycles lead to the following changes in physical-mechanical resistance:

- The elongation at a load of $10 \mathrm{~N} / \mathrm{mm}^{2}$ after cycle I is the same as the control sample, in cycle II it increases by $25 \%$ compared to cycle I; in cycle III it increases by $27 \%$ compared to cycle II and by $45 \%$ compared to cycle I;

- The elongation at break decreases by $19 \%$ in cycle I compared to the control sample, increases in cycle II by $28 \%$ compared to cycle I, and in cycle III is constant compared to cycle II;

- The tensile strength decreases by $9 \%$ in cycle I compared to untreated sample, in cycle II it increases, it is maintaining the same value as in cycle I, and then in cycle III it decreases by $22 \%$ compared to cycles I and II;

- Tear strength decreases by $41 \%$ in cycle I compared to the control sample; in cycle II it increases by $31 \%$ compared to cycle I, and in cycle III it decreases by $56 \%$ compared to cycle II;

- Dimensional stability indicates a surface change after cycle I of $4.4 \%$, which increases in cycle II and cycle III, at $6.7 \%$.

The physical-mechanical characteristics of the pig parchment are presented in Table 6 . 
Table 6: Physical-mechanical characteristics of the pig parchment - sample P, for the untreated sample and after the accelerated ageing cycles (cycle I, cycle II, cycle III)

\begin{tabular}{|c|c|c|c|c|c|c|c|c|c|}
\hline \multirow[b]{2}{*}{$\begin{array}{c}\text { Characteristics } \\
\text { Treatment }\end{array}$} & \multirow[b]{2}{*}{$\begin{array}{c}\text { Thickness } \\
\mathrm{mm}\end{array}$} & \multicolumn{2}{|c|}{ Elongation \% } & \multirow[b]{2}{*}{$\begin{array}{c}\text { Tensile } \\
\text { strength } \\
\mathrm{N} / \mathrm{mm}^{2}\end{array}$} & \multirow{2}{*}{$\begin{array}{c}\text { Tear } \\
\text { strength } \\
\mathrm{N} / \mathrm{mm}\end{array}$} & \multicolumn{4}{|c|}{ Dimensional stability (shrinkage) \% } \\
\hline & & $\begin{array}{c}\text { at a load } \\
\text { of } 10 \mathrm{~N} / \\
\mathrm{mm}^{2}\end{array}$ & $\begin{array}{c}\text { at } \\
\text { break }\end{array}$ & & & Length & Width & Surface & Thickness \\
\hline \multirow{3}{*}{$\begin{array}{l}\text { Sample P } \\
\text { untreated }\end{array}$} & $a-0.75$ & 6 & 26 & 62.3 & 59.0 & & & & \\
\hline & $b-0.96$ & 8 & 28 & 54.7 & 43.5 & & & & \\
\hline & average & 7 & 27 & 58.5 & 51.2 & & & & \\
\hline \multicolumn{10}{|c|}{ Parchment P exposed to artificial ageing } \\
\hline \multirow{3}{*}{$\begin{array}{c}\text { Ageing } \\
7 \text { days }-70^{\circ} \mathrm{C} \\
\text { cycle I }\end{array}$} & $a-0.86$ & 6 & 28 & 68.7 & 48.8 & 4.3 & 5.0 & 9.2 & 3.6 \\
\hline & $b-0.86$ & 8 & 36 & 69.3 & 43.8 & 4.8 & 4.6 & 9.3 & 0 \\
\hline & average & 7 & 32 & 69.0 & 46.3 & 4.5 & 4.8 & 9.2 & - \\
\hline \multirow{3}{*}{$\begin{array}{c}\text { Ageing } \\
14 \text { days }-70^{\circ} \mathrm{C} \\
\text { cycle II }\end{array}$} & $a-0.57$ & 6 & 30 & 51.4 & 36.4 & 5.4 & 5.5 & 10.5 & 5.3 \\
\hline & $b-0.85$ & 6 & 20 & 57.4 & 68.1 & 5.4 & 5.4 & 10.4 & 3.8 \\
\hline & average & 6 & 25 & 54.4 & 52.2 & 5.4 & 5.4 & 10.4 & 4.5 \\
\hline \multirow{3}{*}{$\begin{array}{c}\text { Ageing } \\
21 \text { days }-70^{\circ} \mathrm{C} \\
\text { cycle III }\end{array}$} & $a-1.04$ & 18 & 24 & 63.4 & 62.6 & 5.4 & 5.5 & 10.5 & 8.9 \\
\hline & $b-0.92$ & 6 & 30 & 73.4 & 57.3 & 5.4 & 5.2 & 10.2 & 3.8 \\
\hline & average & 12 & 27 & 68.4 & 60 & 5.4 & 5.3 & 10.3 & 6.3 \\
\hline
\end{tabular}

From Table 6 it can be observed that the applied thermal ageing cycles lead to the following changes of physical-mechanical resistance:

- The elongation at a load of $10 \mathrm{~N} / \mathrm{mm}^{2}$ after cycle I remains constant compared to the control sample, and in cycle III it increases by $41.6 \%$ compared to the control;

- The elongation at break after cycle I has a slight increase of $15.2 \%$ compared to the control sample (initially), and in cycle II and III it remains constant;

- The tensile strength in cycle I and III increases compared to the control by $15 \%$ and remains constant in cycle III;

- The tear strength remains almost constant comparing the values of the specimens with the same thickness;

- The modification of the surface of the parchments is important after cycle I of ageing and remains at the same value after cycles II and III.

\section{CONCLUSION}

In order to simulate a natural ageing process, we investigated the influence/ behaviour of accelerated ageing treatments on parchment samples and evaluated the effects generated. We have exposed new parchments of different animal species i.e., goat, calf, sheep and pig to artificial ageing at $70^{\circ} \mathrm{C}$ in 3 cycles: first cycle for 7 days, second cycle for 14 days and 21 days for the $3^{\text {rd }}$ cycle.

The results of the ageing behaviour showed that the ageing treatment at $70^{\circ} \mathrm{C}$, in several cycles, caused a degradation of the physical mechanical properties of resistance that materialized also by lowering the shrinkage temperature. As the ageing cycle increases, there was a tendency in the values of the physicalmechanical parameters to decrease.

The accelerated ageing treatments affected the shrinkage temperature of the parchment samples. The hydrothermal stability is most affected in sheep and goat parchment samples, it drastically decreased by $15-20 \%$ compared to the untreated samples.

Therefore, it can be stated that the physicalmechanical tests and shrinkage temperature are parameters that can indicate the evolution of the thermal destabilization processes in the collagen matrix.

\section{Acknowledgements}

This work was supported by a grant of the Romanian Ministry of Research and Innovation (now Ministry of Education and Research), CCCDI - UEFISCDI, project number PN-III-P11.2-PCCDI-2017-0878/ no. 55PCCDI/2018, IMPLEMENT, within PNCDI IsII. 


\section{REFERENCES}

1. Larsen, R., Microanalysis of Parchment, Archetype Publications, London, England, 2002.

2. Miu, L., Giurginca, M., Gaidău, C., Bratulescu, V., Meghea, A., Albu, L., Iftimie, N., Bocu, V., Budrugeac, P., Igna, A., Leather and Parchment Heritage Objects, vol. 1: Investigating Deterioration of Heritage Objects (in Romanian), CERTEX Press, Bucharest, 2004.

3. Fuchs, R., The History and Biology of Parchment, Gazette, 2004, 67, 13.

4. Gullick, M., From parchmenter to scribe: some observations on the manufacture and preparation of medieval parchment based upon a review of the literary evidence, Pergament: Geschichte, Struktur, Restaurierung, Herstellung / Hrsg. von Peter Rück, 1991, 145-157.

5. Ryder, M.L., The biology and history of parchment, Pergament: Geschichte, Struktur, Restaurierung, Herstellung / Hrsg. von Peter Rück, 1991, 25-33.

6. Axelsson, K.M., Larsen, R., Sommer, D.V.P., Dimensional studies of specific microscopic fibre structures in deteriorated parchment before and during shrinkage, J Cult Herit, 2012, 13, 2, 128-136, https://doi.org/10.1016/j. culher.2011.08.001.

7. Dumitrescu, G., Badea, E., Parchment... a Story, the Unseen Face of Parchment Documents Issued by the Royal Chancellery in the Time of Stephen the Great (in Romanian), Excelența prin cultura, Bucharest, 2015.

8. Reed, R., The Nature and Making of Parchment, The Elmete Press, 1975.

9. Miu, L., Medieval Documents on Parchments (in Romanian), CERTEX Press, 2007.

10. Fessas, D., Signorelli, M., Schiraldi, A., Kennedy, C.J., Wess, T.J., Hassel, B., Nielsen, K., Thermal analysis on parchments I: DSC and TGA combined approach for heat damage assessment, Thermochim Acta, 2006, 447, 1, 30-35, https://doi.org/10.1016/j. tca.2006.04.007.

11. Jeyapalina, S., Geoffrey, E., Attenburrow, E., Covington, A.D., Dynamic mechanical thermal analysis (DMTA) of leather Part 1: Effect of tanning agent on the glass transition temperature of collagen, J Am Leather Chem As, 2007, 91, 6, 236-242.

12. SR EN ISO 4684:2006.

13. SR EN ISO 4048:2008.

14. SR ISO 5397:1996.

15. SR EN ISO 4047:2002.

16. SR EN ISO 4045:2008.

17. SR ISO 3376:2012.

18. Larsen, R., Poulsen, D.V., Vest, M., The Hydrothermal Stability (Shrinkage Activity) of Parchment Measured by the Micro Hot Table Method (MHT), Microanalysis of Parchment, 2002, 55-62.

19. Balfe, M.P., Humphreys, F.E., The shrinkage temperature of collagen and leather, and the effects of heat and moisture on leather, Progress in Leather Science: 1920- 1945 London: British Leather Manufacturers Research Association, 1947, 415-425.

20. Holst Rasmussen, L., Larsen, R., A simple micro-method for the determination of the shrinkage temperature of leathers, parchments and skins, Zeitschrift für Kunsttechnologie und Konservierung, 2002, 16, 2, 252-256.

(C) 2020 by the author(s). Published by INCDTPICPI, Bucharest, RO. This is an open access article distributed under the terms and conditions of the Creative Commons Attribution license (http:// creativecommons.org/licenses/by/4.0/). 